DRAŽEN CVITANIĆ, Ph.D. ${ }^{1}$

(Corresponding author)

E-mail: drazen.cvitanic@gradst.hr

BILJANA MALJKOVIĆ, mag.ing.aedif. ${ }^{1}$

E-mail: biljana.maljkovic@gradst.hr

${ }^{1}$ University of Split, Faculty of Civil Engineerin,

Architecture and Geodesy

Matice hrvatske 15, 21000 Split, Croatia
Safety and Security in Traffic

Preliminary Communication

Submitted: 9 Oct. 2018

Accepted: 14 June 2019

\title{
DETERMINATION OF APPLICABLE ADJACENT HORIZONTAL CURVE RADII USING OPERATING SPEED
}

\begin{abstract}
Design of curves and their adjacent elements presents the greatest safety problem on rural two-lane roads. The use of the existing alignment consistency safety criteria (design, operating speed, and driving dynamic consistency) could have some shortcomings, especially in countries where the project or design speed is in use instead of (higher) operating speed. The consequence is that the designer should use smaller cross fall on curves than needed, while the calculated side friction is lower than in reality. Further, the existing graphs of adjacent curve radii do not take into account that there is a maximum operating speed achieved for a certain radius or long tangent above which it does not increase. This paper presents a methodology for determination of adjacent horizontal curve radii, with and without tangent between, based on the operating speed models which include dependence of operating speeds on tangents and curves on speed of adjacent alignment elements as well as maximum tangent and curve speed. The developed graphs of adjacent radii at the same time include the limiting values of driving dynamic consistency criteria, so the road designer does not need to calculate permissible and demand side friction for every combination of adjacent alignment elements.
\end{abstract}

\section{KEY WORDS}

operating speed; adjacent radii; alignment consistency;

\section{INTRODUCTION}

A good road design implies the selection of alignment elements enabling constant driving speed along homogeneous segments, thus providing efficient, comfortable and safe driving. The design of curves and their adjacent elements presents the greatest safety problem on rural two-lane roads. Based on statistics from different countries, Lamm et al. [1] have found that more than $50 \%$ of the fatalities occur on rural two-lane roads and at least half of them are related to curves [2]. More detailed studies show that the accident rates are significantly higher in sharp curves with radii smaller than $200 \mathrm{~m}$ [3, 4].
According to the Final Report of the ERA-NET programme [5], 45\% of fatal accidents are single-vehicle or run-off-road accidents which usually occur in horizontal curves due to loss of vehicle control or stability [6] as a result of exceeding the limiting values of side friction because the driver drives too fast to safely negotiate the curve. Baldwin in [7] showed that, while the accident rate increases as the radius of horizontal curve decreases, the accident rate for sharp curves decreases as the frequency of curves (per length of highway) increases. This shows that there is a connection between the traffic safety and consistency of alignment elements which ensures that successive road elements provide uniform driving speed in line with the driver's expectations [8].

The most common used measure of consistency is speed. Almost all of the road design guidelines define some relevant speed value as the basis for choosing appropriate dimensions of alignment elements. The guidelines of some countries use design speed, others use the so called project speed in addition to design speed, and today many of them use the operating speed. These speeds are briefly described further in the text.

\section{Design speed}

For many years, the basis of most road design guidelines has been the design speed concept. The design speed is determined based on the road and terrain category. It is used to determine the minimum radius of horizontal curve $R_{\text {min }}$ [m] from the equation of vehicle stability in the curve for the design speed $V_{d}[\mathrm{~km} / \mathrm{h}]$, the maximum permissible superelevation $e_{\text {max }}[\%]$ and permissible side friction factor $f_{\text {Rperm }}$ :

$$
R_{\text {min }}=\frac{V_{d}^{2}}{127\left(\frac{e_{\max }}{100}+f_{\text {Rpern }}\right)}
$$

In this way, the safe driving speed is provided on curves with minimum radius. Most guidelines recommend the application of minimum radius only in exceptional situations and designers are encouraged to adopt higher speeds. Subsequently, the alignments created 
on this concept may generate the operating speeds that fluctuate considerably along the different road sections which presents a significant safety problem.

\section{Project speed}

The project speed is the maximum expected speed in free flow conditions which can be achieved with sufficient safety on a particular part of the road segment depending on its horizontal and vertical characteristics. Its value is usually determined by Equation 1 as a function of applied curve radius (as in Croatia [9] and a few other EU countries). It is used for determination of cross fall and stopping sight distance on flatter curves.

\section{Operating speed}

The operating speed is used in some guidelines instead of project speed (because it is a theoretical value). The operating speed is defined as $85 \%$ value of the free flow speed distribution on a particular element of the road. Many factors affect the free flow speed of vehicles. It was found that the greatest impact on the passenger car free-flow speed have radii of horizontal curves. Much less influence has grade, vertical alignment and the cross section characteristics. The most recent review of the operating speed models in various parts of the world is given in [10]. Several studies have shown that the free-flow speed in curves with radii $R<500 \mathrm{~m}$ is most influenced by the curvature of the road and the approach speed (i.e. speed at which a vehicle approaches a curve).

Since the design and project speed concept showed a lot of deficiencies, in the last decades many researchers have conducted numerous investigations of the relationship among the design, project, and the actual (operating) speed on the curves. Speed studies on road with design speed below $100 \mathrm{~km} / \mathrm{h}$ [11, 12] showed that the average and operating speed in curves were generally above the design and project speed. It leads to the underestimation of the needed cross fall (according to Equation 1) and the stopping sight distance on curved sections, which represents critical safety issues of consistent road design. So, the recommendation is to use the operating speed for achieving consistent road as well as for determination of cross fall and stopping site distance on curved sections. In this research, curve and tangent operating speed models were used as input in alignment consistency criteria in order to improve the road design process.

Table 1 - Ranges for the consistency safety criteria [2]

\section{ALIGNMENT CONSISTENCY CRITERIA}

Road design approach ensuring high level of consistency, based on vehicle operating speed, has been adopted in some European countries. The German studies were the first ones to introduce the operating speed concept in order to achieve consistent alignment (guidelines editions: 1973, 1984 and 1995) [13]. In addition to Germany, many other European countries use three safety criteria for achieving consistency, [2]:

1) Design consistency;

2) Operating speed consistency;

3) Driving dynamic consistency.

The limiting values of these criteria are shown in Table 1.

Criterion 1 refers to the adjustment of alignment elements, so the absolute difference between design $V_{d}$ and operating speed $V_{85}$ (or project speed $V_{p}$ in some countries) on each element would be within certain range limits $(10 \mathrm{~km} / \mathrm{h}$ in good area, $20 \mathrm{~km} / \mathrm{h}$ in acceptable - fair area).

Criterion 2 requires that the operating speed (or project speed) on adjacent elements are within certain range limits.

Different expressions for operating speed estimation have been developed based on research in many countries [10]. All expressions include the dependence of the operating speed on road curvature. Here is presented the equation based on the research carried out by Lamm:

$V_{85}=\frac{10^{6}}{\left(8270+8.01 \cdot C C R_{s}\right)}$

where $C C R_{s}$ [gon/km] is curvature change rate:

$C C R_{s}=\frac{\left(\frac{L_{c r}}{R}+\frac{L_{c l 1}}{2 R} \frac{L_{c l 2}}{2 R}\right)}{L} \cdot 63700$

where: $L=L_{c r}+L_{c l 1}+L_{c l 2}$ length of curve [km]; $L_{c r}$ length of circular curve [m]; $L_{c l 1}, L_{c l 2}$ length of clothoids [m].

Using Expression 2 the operating speeds on adjacent alignment elements can be calculated and compared (Criteria 1 and 2). Based on Criterion 2, the diagram of the relationship between radii of adjacent curves, shown in Figure 1, was developed.

German guidelines use this graph not only for determination of adjacent curves radius, but also for determination of radii of curves with tangent between

\begin{tabular}{||l|c|c|c||}
\hline Safety criterion & Good & Fair & Poor \\
\hline \hline Criterion 1 & $\left|V_{85}^{i}-V_{d}\right| \leq 10[\mathrm{~km} / \mathrm{h}]$ & $10<\left|V_{85}^{i}-V_{d}\right| \leq 20[\mathrm{~km} / \mathrm{h}]$ & $20<\left|V_{85}^{i}-V_{d}\right|[\mathrm{km} / \mathrm{h}]$ \\
\hline Criterion 2 & $\left|V_{85}^{i}-V_{85}^{i+1}\right| \leq 10[\mathrm{~km} / \mathrm{h}]$ & $10<\left|V_{85}^{i}-V_{85}^{i+1}\right| \leq 20[\mathrm{~km} / \mathrm{h}]$ & $20<\left|V_{85}^{i}-V_{85}^{i+1}\right|[\mathrm{km} / \mathrm{h}]$ \\
\hline Criterion 3 & $0.01 .<f_{R D}-f_{\text {Rperm }}$ & $-0.04 .<f_{R D}-f_{R p e r m} \leq 0.01$ & $f_{R D}-f_{\text {Rperm }}<-0.04$ \\
\hline \hline
\end{tabular}




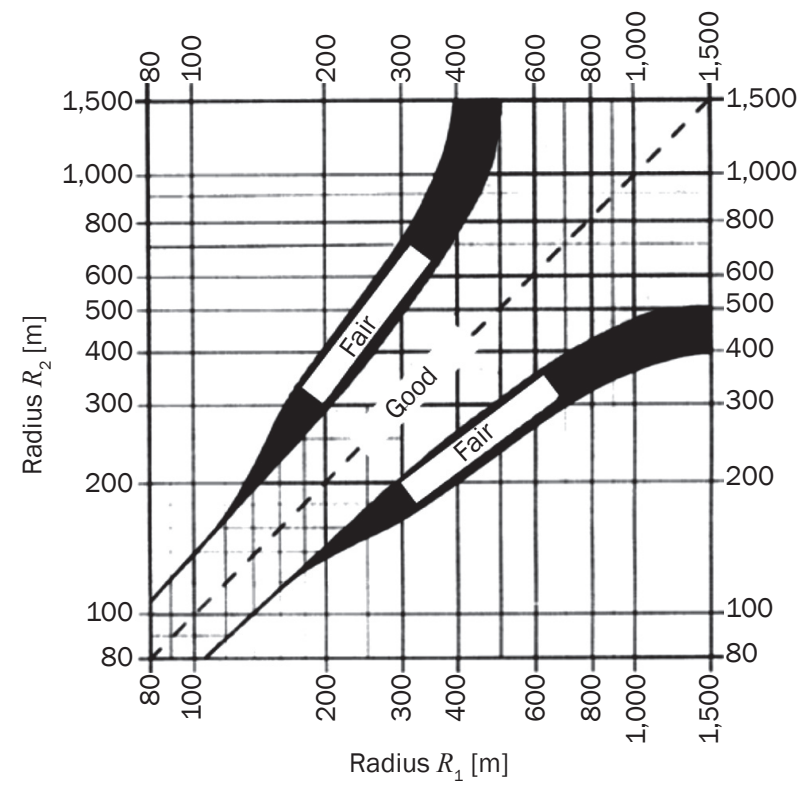

Figure 1 - The relationship of adjacent curve radii [13]

them (for tangents with lengths $L<300 \mathrm{~m}$ ). Also, they give recommendation of applicable tangent length in dependence of adjacent curve radii.

Criterion 3 deals with vehicle stability. The loss of vehicle stability on horizontal curves can be result of excessive centripetal force, i.e. it may be due to exceeding the limiting values of side friction. So, this criterion requires that the actual (demand) value of side friction $f_{R D}$ (due to operating speed) is not significantly greater than the allowable design (permissible) value $f_{\text {Rperm }}$ (defined for the design or project speed).

Maximum permissible side friction factors are based on skid resistance studies. For the safety reasons, the $95^{\text {th }}$ percentile distribution curve is used to determine the maximum tangential friction factors which means that only $5 \%$ of the measured values are smaller (for the worst possible combination: worn tires, worn and wet pavement). Based on the maximum tangential friction factors of the selected countries (Germany, France, Sweden, Switzerland and the United States), Lamm et al. in [1] established an overall regression relationship between the maximum tangential friction factor $f_{T}$ and design speed $V_{d}[\mathrm{~km} / \mathrm{h}]$ as:

$$
f_{T}=0.59-4.85 \cdot 10^{-3} \cdot V_{d}+1.51 \cdot 10^{-5} \cdot V_{d}^{2}
$$

which is used in this research.

The side friction supply $f_{\text {Rsupply }}$ is a fraction of tangential friction, reduced due to tyre-specific influences which is defined by Equation 5. The permissible or design side friction factor can be determined according to side friction supply $f_{\text {Rsupply }}$ and utilization ratio $n$ (6).

$$
\begin{aligned}
& f_{\text {Rsupply }}=0.925 \cdot f_{T} \\
& f_{\text {Rperm }}=n \cdot f_{\text {Rsupply }} \\
& n=0.6
\end{aligned}
$$

The utilization ratio $n$ varies between 40 to $60 \%$ for rural roads, with respect to the topography and whether it is an existing road. This results in the fact that there will still be 83 to $93 \%$ of friction available in the tangential direction for acceleration, deceleration or some evasive manoeuvers when driving through curves [13].

Side friction demand $f_{R D}$ can be calculated from the basic equation of vehicle stability on horizontal curves (1), using operating speed $V_{85}[\mathrm{~km} / \mathrm{h}]$, radius of horizontal curve $R$ [m] and superelevation rate $e$ [\%]:

$$
f_{R D}=\frac{V_{85}^{2}}{127 \cdot R}-0.01 \cdot e
$$

For this criterion the difference between permissible side friction and demand side friction has to be positive i.e. greater than 0.01 in good area, and it can be negative (up to -0.04) for fair area. This negative value does not imply that the vehicle will lose stability, because there is low probability that the situation with worn tires, worn and wet pavement in combination with sudden braking will happen.

\section{MOTIVATION AND RESEARCH OBJECTIVES}

Although the concept of operating speed improved the road design process, the use of these three criteria, in conjunction with outdated operating speed models, could lead to a few shortcomings in designing successive road alignment elements, especially in the following circumstances:

1) The graph of adjacent curve radii (Figure 1; Equation 2) does not take into account that there is a maximum operating speed (ca. $100 \mathrm{~km} / \mathrm{h}$ ) achieved for a certain radius or long tangents [14, 15] above which it does not increase regardless of the increase in radius curve or tangent length. So, the calculated demand side friction (for calculated speeds higher than $100 \mathrm{~km} / \mathrm{h}$ ) would be higher than in reality (Criteria 2 and 3 ).

2) The maximum speed on tangent depends not only on the tangent's length but also on the value of curve radius before tangent as shown in $[16,17]$, which the existing criteria do not take into account.

3 ) In the guidelines which use the project speed instead of (higher) operating speed, a smaller cross fall on curves than needed would be used, while the calculated demand side friction is lower than in reality, which can lead to unsafe situations (Criterion 3). The primary objective of this research was to develop the reliable graphs of applicable adjacent elements dimensions, based on operating speed models which include dependency of tangent and curve operating speed on speed of adjacent alignment elements, as well as maximum reachable tangent and curve speed (Criterion 2). The second objective was that the mentioned graphs at the same time include limiting 
values of Criterion 3 (side friction difference) so the road designer does not need to calculate permissible and demand side friction for every combination of adjacent alignment elements.

\section{USED SPEED MODELS}

In this research speed models developed on 20 $\mathrm{km}$-long state road segment [18] were used. The analysed road segment is a two-lane rural state road with a relatively low traffic volume (the average annual daily traffic is about 1,400 veh/day) and no intersections with major roads. The test rides were recorded during the day under optimal weather and free-flow conditions in order to reduce the conditions not related to the geometry of the alignment $[19,20]$.

Operating speed prediction models were developed based on the speed data from an $18 \mathrm{~km}$-long road segment, and the model validation was made with the data from a $2 \mathrm{~km}$-long segment of the road. The analysed $18 \mathrm{~km}$-long section consists of 64 horizontal curves with radii varying from 85 to $1,010 \mathrm{~m}$ and 64 tangents with lengths varying from 10 to 683 $\mathrm{m}$. The geometric characteristics of the analysed road segment are presented in Table 2.

The test driver sample consisted of 20 people at the ages ranging from 23 to 60 and with different driving experiences (from 5 to more than 30 years). The test vehicles were personal cars of different types and ages.

\section{Tangent speed model}

Stepwise multiple linear regression indicated tangent length $T$, radius of the previous curve $R_{b e f}$ and radius of the following curve $R_{\text {aft }}$ as statistically significant independent variables.

The best fit model for predicting the maximum operating speeds on tangent section was [19]:

$\hat{V}_{85}^{T}=13+6.92 \cdot \ln R_{b e f}+3.69 \cdot \ln R_{a f f}+2.97 \cdot \ln T$

The model showed a high coefficient of determination $R^{2}=0.85$. The quality of the model was further evaluated using the mean absolute percentage error
(MAPE). The overall MAPE for the data from the 18 $\mathrm{km}$-long segment was $3.1 \%$. The MAPE of validation section was $1.9 \%$.

\section{Curve speed model}

Several models with radius of curve and approach speed as significant independent variables were examined and the best fit model was [19]:

$\hat{V}_{85}^{C}=2.9+8.23 \cdot \ln R+0.364 \cdot \hat{V}_{85}^{a p p}$

with natural logarithm of horizontal curve radius $(R)$ and estimated approach speed $\left(\hat{V}_{85}^{a p p}\right)$ as independent variables. The coefficient of determination of the model is equal to 0.86 . The overall MAPE was 3.3\%, while MAPE for validation section was 3.6\%.

The best fit model for predicting curve speed depending just on its radius is

$\hat{V}_{85}^{C}=11.77 \cdot \ln R+15.61$

The coefficient of determination was 0.81 . The overall MAPE for the data from the $18 \mathrm{~km}$-long segment is $5 \%$, and for the validation segment it was 3.8\%.

\section{DEVELOPING GRAPHS OF ADJACENT CURVES RADII}

Based on the described operating speed models, graphs of adjacent curves radii were developed for adjacent curves without tangents in between and for the adjacent curves with tangent in between. The applied methodology includes dependency of tangent speed on radii of adjacent curves as well as on the tangent length, and the fact that there is maximum operating speed (ca. $100 \mathrm{~km} / \mathrm{h}$ ) reached for certain flatter curves and long tangents.

\subsection{Adjacent curves without tangents between them}

For the calculation of operating speed $V_{\text {Rbef }}$ on a curve before the subject curve (Figure 2) Equation 10 was used and for subject curve speed $V_{R}$ Equation 9 was used.

Table 2 - Geometric characteristics of the analysed road segment [18]

\begin{tabular}{||l|l|c|c|c|c||}
\hline \multicolumn{1}{|c|}{ Element } & \multicolumn{1}{|c|}{ Geometric characteristics } & Min & Max & Mean & St. dev. \\
\hline \hline \multirow{3}{*}{ Curve } & Radius [m] & 85 & 1,010 & 300 & 229 \\
\cline { 2 - 7 } & Length [m] & 40 & 440 & 147 & 99 \\
\cline { 2 - 7 } & Deflection [ ${ }^{\circ}$ ] & 4 & 118 & 41 & 28 \\
\cline { 2 - 7 } & Elevation [\%] & 2 & 7 & 3.4 & 1.4 \\
\hline \multirow{2}{*}{ Tangent } & Length [m] & 0 & 683 & 101 & 110 \\
\hline Clothoid & Length [m] & 0 & 60 & 32 & 10 \\
\hline Hor. alignment & Grade [\%] & 0.5 & 6 & 2.1 & 1.5 \\
\hline
\end{tabular}




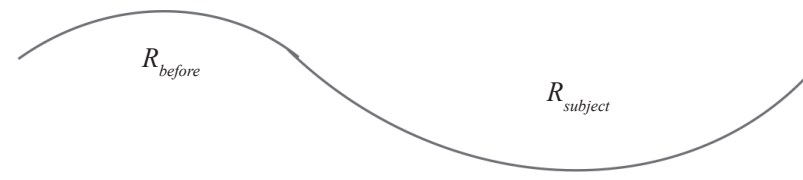

Figure 2 - Analysed radii

Maximal coefficient of friction $f_{\text {Tmax }}$ was calculated according to Equation 4, supply side friction $f_{\text {Rsupp }}$ according to Equation 5, permissible side friction $f_{\text {Rperm }}$ according to Equation 6 and side friction demand $f_{R D}$ according to Equation 7.

Table 3 presents the calculated limiting values of preceding radii $R_{b e f}$ in the fair area, according to the limiting value of Criterion $3\left(\Delta f_{\text {Rperm }}=-0,04\right)$. Speeds difference $\left(\Delta V=V_{\text {Rbef }}-V_{R}\right)$ in all cases satisfies Criterion $2(\leq 20 \mathrm{~km} / \mathrm{h})$.

The results are presented graphically in Figure 3. One can see that the lowest applicable radius is $R=140 \mathrm{~m}(\Delta f=-0.04)$ while the smaller radius cannot be used regardless of the chosen design speed, because operating speeds are higher than design speeds, so that the resulting side frictions difference is higher as well.

The same analysis was made for the good area (speed difference less than $10 \mathrm{~km} / \mathrm{h}$ and $\Delta f>0.01$ ).

The graph is presented in Figure 4.

One can see that the minimum usable radius for the good area is $200 \mathrm{~m}$ for max $R_{b e f}$ of $210 \mathrm{~m}$ which coincides with Raff conclusion [3], that the curves with radius smaller than $200 \mathrm{~m}$ are most dangerous locations on roads.

Graph of adjacent curve radii which satisfies both criteria for good and fair area was made for different cross slopes (from 3\% up to $7 \%$ with increment of 1\%) of road cross section as presented in Figure 5.

In the fair area, the minimum permissible preceding curve radii $R_{b e f}$ for the subject radius of $140 \mathrm{~m}$ is $180 \mathrm{~m}$ (for cross slope of 7\%). According to consistency criteria, for radii greater than $200 \mathrm{~m}$, the preceding radius can take any value because of reaching the maximum

Table 3 - Adjacent curves radii for fair area

\begin{tabular}{||c|c|c|c|c|c|c|c|c|c|c||}
\hline$R_{\text {bef }}[\mathrm{m}]$ & $R[\mathrm{~m}]$ & $R_{\text {bef }}[\mathrm{km} / \mathrm{h}]$ & $V_{R}[\mathrm{~km} / \mathrm{h}]$ & $\Delta V[\mathrm{~km} / \mathrm{h}]$ & $F_{\text {Tmax }}$ & $F_{R s u p p}$ & $F_{\text {Rperm }}$ & $F_{R D}$ & $\Delta f_{\text {Rperm }}$ & $\Delta f_{\text {Rsupp }}$ \\
\hline \hline 75 & 75 & 66.4 & 62.6 & 4 & 0.346 & 0.320 & 0.192 & 0.341 & -0.149 & -0.022 \\
\hline 100 & 100 & 69.8 & 66.2 & 4 & 0.335 & 0.310 & 0.186 & 0.275 & -0.089 & 0.035 \\
\hline 120 & 120 & 72.0 & 68.5 & 3 & 0.329 & 0.304 & 0.182 & 0.238 & -0.055 & 0.066 \\
\hline 130 & 130 & 72.9 & 69.5 & 3 & 0.326 & 0.301 & 0.181 & 0.222 & -0.041 & 0.079 \\
\hline 181 & 140 & 76.8 & 71.5 & 5 & 0.320 & 0.296 & 0.178 & 0.217 & -0.040 & 0.079 \\
\hline 260 & 150 & 81.1 & 73.6 & 7 & 0.315 & 0.291 & 0.175 & 0.214 & -0.040 & 0.077 \\
\hline 370 & 160 & 85.2 & 75.7 & 10 & 0.309 & 0.286 & 0.172 & 0.212 & -0.040 & 0.075 \\
\hline 520 & 170 & 89.2 & 77.6 & 12 & 0.304 & 0.282 & 0.169 & 0.209 & -0.040 & 0.073 \\
\hline 720 & 180 & 93.0 & 79.5 & 14 & 0.300 & 0.277 & 0.166 & 0.206 & -0.040 & 0.071 \\
\hline 1,000 & 190 & 96.9 & 81.4 & 16 & 0.295 & 0.273 & 0.164 & 0.204 & -0.040 & 0.069 \\
\hline 1,350 & 200 & 100.4 & 83.1 & 17 & 0.291 & 0.269 & 0.162 & 0.201 & -0.040 & 0.068 \\
\hline
\end{tabular}

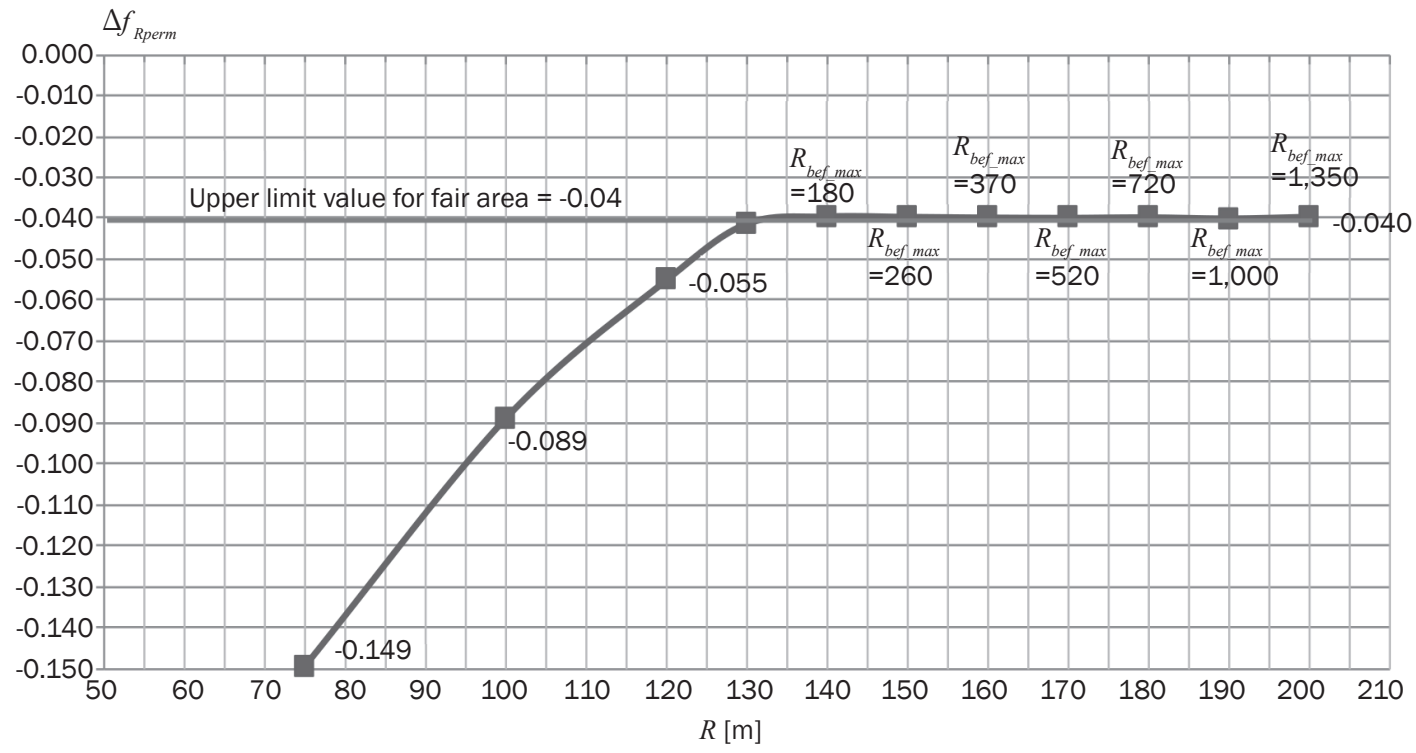

Figure 3 - Applicable adjacent radii for fair area 


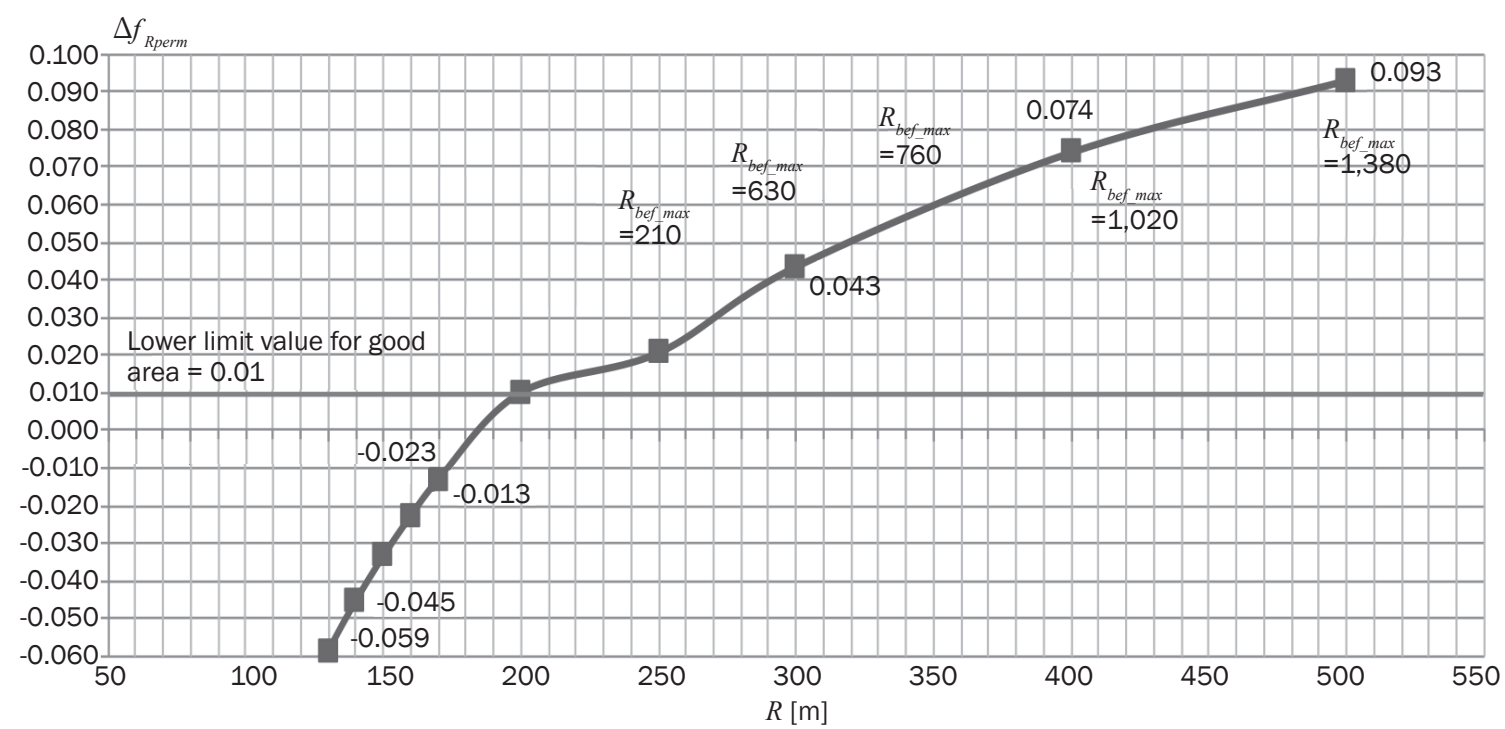

Figure 4 - Applicable adjacent radii for good area

attainable speed $(\sim 100 \mathrm{~km} / \mathrm{h})$ as well as the highest side friction demand, so side friction differences are always in the fair area and speed difference is less than $20 \mathrm{~km} / \mathrm{h}$.

In the good area the minimum applicable radius of subject curve is $200 \mathrm{~m}$ with the preceding maximum radius of $210 \mathrm{~m}$ (when cross slope of 6 or $7 \%$ is used). For radii greater than $500 \mathrm{~m}$ all values of the preceding radii satisfy consistency criteria because of reaching maximum speed, i.e. demand side friction, so differences are always in the good area.

\subsection{Adjacent curves with tangents between}

According to the Croatian and some other guidelines the suggested minimum length of tangent $(\mathrm{m})$ between two counterflow curves is two times the project speed $\left(2 V_{p}\right)$. It is considered that this length allows the driver to prepare for the next curve. According to the Croatian guidelines the maximum length of tangent is $20 \mathrm{Vp}$, while German guidelines limit the length on $1,500 \mathrm{~m}$ because of the monotony of driving and discouragement of driving fast.

The graphs were made for different tangent lengths, starting for minimum tangent length $T_{\min }$ up to the maximum tangent length, with a step of $2 T_{\text {min }}$.
For the example, Table 4 presents the results for the fair area, curves with cross fall of $7 \%$ and minimum tangent length between curves (170 m 2 $V_{p}$ ). Because the speed on tangent depends on the radius of the preceding curve too, here the radii of the preceding curve $R_{\text {bef }}$ which marginally satisfy criteria 3 $(\Delta f=-0.04)$ were determined.

Calculations have been made with other tangent lengths $\left(2 T_{\min }, 4 T_{\min }\right.$ up to $\left.T_{\max }=1,500 \mathrm{~m}\right)$ for the fair and good area and the resulting graph is presented in Figure 6.

One can see that the minimum applicable radius in the fair area is $150 \mathrm{~m}$ (using minimum tangent length) which is almost the same value as for the adjacent curves without the tangent between. As the tangent length increases, the minimum preceding radius $R_{\text {bef }}$ as well as the subject curve radius $R$ increase too, due to higher side friction caused by the higher operating speeds on longer tangents. For the radius greater than $200 \mathrm{~m}$ any value of the preceding curve radius for all tangent lengths could be used due to achieving the limiting operating speed of $100 \mathrm{~km} / \mathrm{h}$, so there is no increase in the side friction demand. Regarding the good area, the minimum applicable radius is $220 \mathrm{~m}$, with the preceding radius in the range from 250 to $450 \mathrm{~m}$ depending of the tangent length. For the radii

Table 4 - Applicable radii of adjacent curves with minimal tangent length between $(170 \mathrm{~m})$

\begin{tabular}{||c|c|c|c|c|c|c|c|c|c|c|c||}
\hline \hline$R_{\text {bef }}[\mathrm{m}]$ & $T[\mathrm{~m}]$ & $V_{T}[\mathrm{~km} / \mathrm{h}]$ & $R[\mathrm{~m}]$ & $V_{R}[\mathrm{~km} / \mathrm{h}]$ & $\Delta V[\mathrm{~km} / \mathrm{h}]$ & $f_{\text {tmax }}$ & $f_{\text {rmax }}$ & $f_{\text {rperm }}$ & $f_{r}$ & $\Delta f_{\text {rperm }}$ & $\Delta f_{\text {rsupp }}$ \\
\hline \hline 125 & 170 & 79.6 & 125 & 71.6 & 8 & 0.32 & 0.30 & 0.18 & 0.25 & -0.08 & 0.04 \\
\hline 150 & 170 & 81.4 & 150 & 73.8 & 8 & 0.31 & 0.29 & 0.17 & 0.22 & -0.04 & 0.08 \\
\hline 260 & 170 & 85.4 & 160 & 75.8 & 10 & 0.31 & 0.29 & 0.17 & 0.21 & -0.04 & 0.07 \\
\hline 440 & 170 & 89.3 & 170 & 77.7 & 12 & 0.30 & 0.28 & 0.17 & 0.21 & -0.04 & 0.07 \\
\hline 750 & 170 & 93.2 & 180 & 79.6 & 14 & 0.30 & 0.28 & 0.17 & 0.21 & -0.04 & 0.07 \\
\hline 1,250 & 170 & 96.9 & 190 & 81.4 & 16 & 0.30 & 0.27 & 0.16 & 0.20 & -0.04 & 0.07 \\
\hline
\end{tabular}


greater than $500 \mathrm{~m}$ all combinations of the preceding curve radius and tangent length are permissible due to achieving the maximum speed i.e. side friction demand.

\section{DISCUSSION}

The design speed concept for the determination of the minimum radius according to Equation 1 is practically outdated because the operating speed is much higher than design and project speed, which are used for the determination of cross slope and sight distance. In this way, the designed cross slope and sight distance are underestimated for faster drivers who are most often involved in road accidents. The uselessness of this concept is especially emphasized for lower road categories i.e. roads with lower design speeds. For example, the minimum radius for the design speed of $50 \mathrm{~km} / \mathrm{h}$ is in all guidelines about $80 \mathrm{~m}$. From Graphs 5 and 6 one can see that the minimum radius on which Criterion 3 can be satisfied is $140 \mathrm{~m}$ for the adjacent curves in the fair area, i.e. $150 \mathrm{~m}$ for the curve with the preceding tangent.

For the good area the minimum applicable curve radius is greater than $200 \mathrm{~m}$ for both cases: with and without tangent between. This is probably the main reason why accident statistics shows that the accident rates are significantly higher in sharp curves with radii smaller than $200 \mathrm{~m}$ [3].

Using the driving dynamic consistency criteria in conjunction with maximal achievable speed on long tangents and flat curves, results with the fact, that according to the developed graphs, one can use any value of the preceding radius for subject radius greater than $200 \mathrm{~m}$, which is not a rationale solution in terms of road visual appearance, monotony of driving, and consequent safety. The research conducted in the USA, namely, showed how the number of accidents increases exponentially when the difference of adjacent vehicle speeds is higher than $15 \mathrm{~km} / \mathrm{h}$ [21]. Considering the operating speed used by a minority of drivers (15\%) it could be expected that the difference of speed between slower and faster drivers (vehicles) would be significant. For example, on the analysed road section, there were two adjacent curves with radii of 800 and $140 \mathrm{~m}$, respectively. The average speed on the curve with $R=140 \mathrm{~m}$ was $88.7 \mathrm{~km} / / \mathrm{h}$, standard deviation was $9.2 \mathrm{~km} / \mathrm{h}$, so the operating speed (85\% percentile) was $98.3 \mathrm{~km} / \mathrm{h}$ while $15 \%$ of speed was 79.13 . The speed difference between slow and fast drivers was $19.13 \mathrm{~km} / \mathrm{h}$ on the same road element. So the author's opinion is how the limiting values of speed difference, particularly for the fair area, should be lowered at least to $15 \mathrm{~km} / \mathrm{h}$.

From Figure 6 one can see how the values of adjacent curves radii from the German guidelines (Figure 1) correspond pretty well with the values calculated here for the tangent length of $2 T_{\min }$ but are significantly larger than the calculated applicable radii for longer tangents. The main reason of this discrepancy is a consequence of taking into account the fact that the curve operating speed depends on the preceding tangent length. It is something the designer should take into account while choosing the appropriate length of tangents, i.e. adjacent curves radii.

According to the results of the research it could be recommended how the minimum radius of minor rural roads should be greater than $150 \mathrm{~m}$, instead of $80 \mathrm{~m}$ as shown in the graph presented in Figure 1, while higher-category roads should have minimum radius greater than $200 \mathrm{~m}$ regardless of the design speed. This is in accordance with the latest German guidelines [22] which for the first time do not use the concept of design speed.

\section{CONCLUSION}

The existing methodology for the selection of applicable adjacent curve radii have a few shortcomings, especially when used in conjunction with the design or project speed, instead of operating speed. Since the operating speed is higher than design and project speed, the designers use smaller cross fall on curves than needed. Further, speed on tangents depends on the speed of the previous curve while speed on long tangents reaches some maximum value after which it does not increase regardless of the tangent length, which is not taken into account by the current design praxis. For the above reasons, here is presented the contribution to the new methodology for determination of adjacent horizontal curve radii, with and without tangent between. The methodology is based on the operating speed models which include dependency of operating speeds on tangents and curves on speeds of the adjacent alignment elements, as well as maximum tangent (curve) speed.

The developed graphs of adjacent radii at the same time include the limiting values of driving dynamic consistency criteria, so the road designer does not need to calculate permissible and demand side friction for every combination of adjacent alignment elements. The main findings of the research are:

1) For curves without tangents between, the minimal applicable radius is $R=140 \mathrm{~m}$ in fair area, i.e. $\mathrm{min}$. $R=200 \mathrm{~m}$ in good area, regardless of the design speed.

2) For adjacent curves with tangent between, minimal applicable radius is $150 \mathrm{~m}$ in the fair area for the minimum tangent length. As the tangent length increases the minimum preceding radius $R_{b e f}$ as well as the subject curve radius $R$ increase too, due to higher side friction caused by the higher operating speeds on longer tangents. In good area, the 


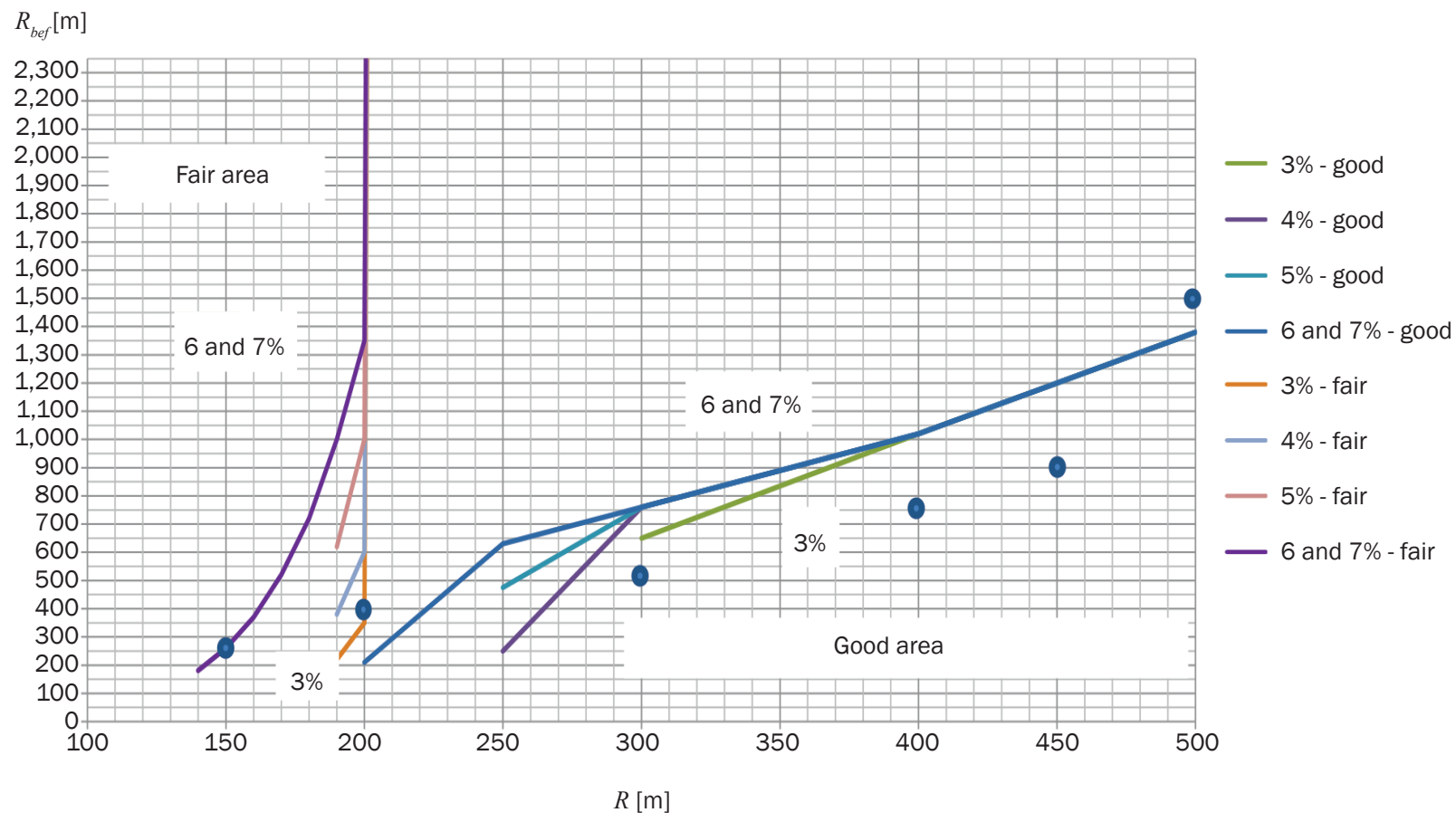

Figure 5 - Applicable adjacent radii for good and fair area for different cross slopes *With are marked the values corresponding to Figure 1

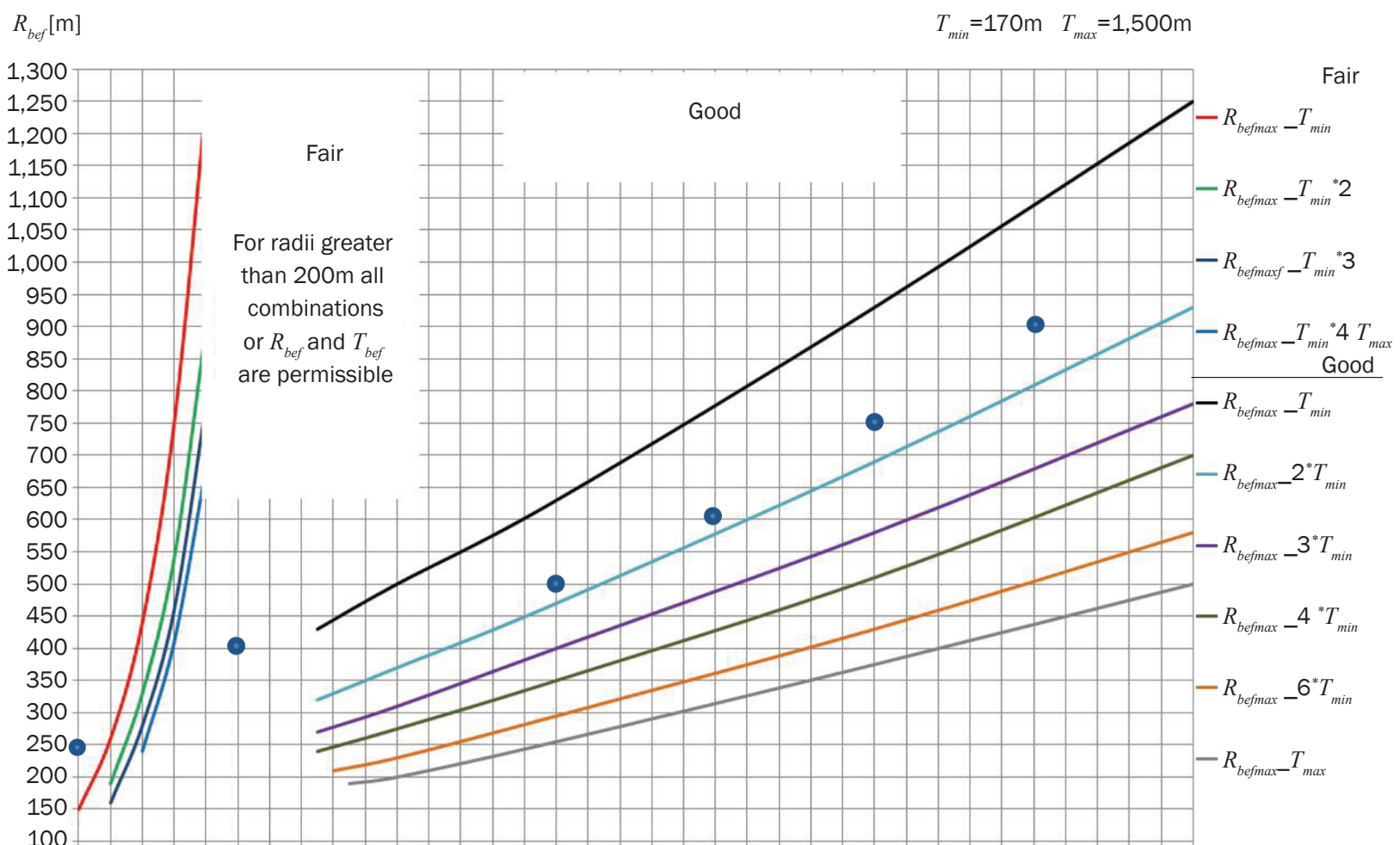

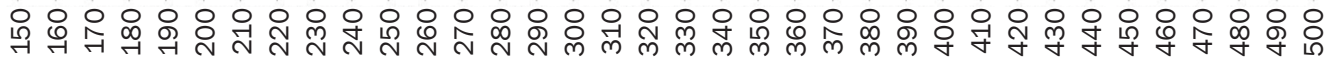

$R[\mathrm{~m}]$

Figure 6 - Applicable adjacent radii with tangent between for good and fair area *With $\bullet$ are marked the values corresponding to Figure 1 
minimal applicable radius is $220 \mathrm{~m}$, with the preceding radius in the range from 250 to $450 \mathrm{~m}$ depending on the tangent length.

3) In the fair area, the speed difference used in Criterion 2 should be decreased at least to $15 \mathrm{~km} / \mathrm{h}$.

The authors believe that the greatest contribution of this research is in the physical explanation of the most common causes of curve accidents according to road accident statistics data $[3,21]$.

DRAŽEN CVITANIĆ, dr. sc. ${ }^{1}$

E-mail: drazen.cvitanic@gradst.hr

BILANA MALJKOVIĆ, mag. ing. aedif. ${ }^{1}$

E-mail: biljana.maljkovic@gradst.hr

${ }^{1}$ Sveučilište u Splitu

Fakultet građevinarstva, arhitekture i geodezije

Matice hrvatske 15, 21000 Split, Hrvatska

\section{ODREĐIVANJE PRIMIJENJIVIH RADIJUSA SUSJEDNIH ZAVOJA NA TEMELUU OPERATIVNE BRZINE}

\section{SAŽETAK}

Pravilno projektiranje zavoja i njima susjednih elemenata trase predstavlja najvažniji siguronosni problem na dvotračnim vangradskim cestama. Korištenje postojećih kriterija konzinstencije trase (kriterij odnosa projektne $i$ operativnih brzina te kriterij dinamike vožnje) ima nekoliko nedostataka, naročito u državama u kojima se kod analize konzistencije trase koriste projektna i računska brzina, ne uzimajući u obzir operativnu brzinu koja je u načelu veća. Posljedica navedenog je da projektanti koriste poprečni nagib kolnika u zavoju manji od potrebnog, a proračunati radijalni otpor trenja je manji od stvarnog. Nadalje, dijagrami vrijednosti polumjera susjednih zavoja ne uzimaju u obzir da postoji granična - najveća operativna brzina koja se dostiže za određene radijuse ili duge tangente, koja se ne povećava daljnjim povećanjem polumjera zavoja ili duljine pravca. Ovaj članak prikazuje metodologiju za određivanje veličine susjednih polumjera zavoja, s ili bez međupravca između njih, koja se temelji na modelu operativne brzine koji uključuje zavisnost operativne brzine na pravcima i zavojima o brzinama na susjednim elementima trase, kao i maksimalnu vrijednost ooperativne brzine koja se može postići u blagim zavojima ili na dugim pravcima. Izrađeni dijagrami vrijednosti polumjera susjednih zavoja također uključuju i granične vrijednosti kriterija dinamike vožnje, pa projektant ne mora računati vrijednosti dopuštenog i stvarnog radijalnog otpora trenja za razne kombinacije veličina susjednih elemenata trase.

\section{KLUUČNE RIJEČl}

operativna brzina; susjedni polumjeri krivina; konzistencija toka trase;

\section{REFERENCES}

[1] Lamm R, Psarianos B, Choueiri, E. M, Soilemezoglou, G. A Practical Safety Approach to Highway Geometric Design International Case Studies: Germany, Greece, Lebanon, and the United States. Proc. of the International
Symposium on Highway Geometric Design Practices, 30 Aug. - 1 Sep. 1995, Boston, MA, USA; 1995. p. 1-9. Available from: http://onlinepubs.trb.org/Onlinepubs/ circulars/ec003/ch9.pdf

[2] Lamm R, Choueriri EM, Mailaender T. Traffic Safety on Two Continents-a ten-year Analysis of Human and Vehicular Involments. Proccedings SHRP, Goutenberg, Sweden; 1992. p. 18-20.

[3] Raff MS. Interstate Highway Accident Study. Highway Research Board Bulletin 74: Traffic Accident Studies. Washington D.C.; 1953. p. 18-45. Available from: http://onlinepubs.trb.org/Onlinepubs/hrbbulletin/74/74-003.pdf

[4] PIARC Technical Committee on Road Safety. Road Safety Manual. World Road Association; 2003. 602 p. Available from: https://roadsafety.piarc.org/en

[5] ERA-NET ROAD. Safety at the Heart of Road Design. Final Report of the ERA-NET programme, 2012.

[6] Torbic DJ, Harwood DW, Gilmore DK, Pfefer R, Neuman TR, Slack KL, Hardy KK. Guidance for Implementation of the AASHTO Strategic Highway Safety Plan: A Guide for Reducing Collisions on Horizontal Curves. NCHRP Report 500 Series, Vol. 7, Transportation Research Board, Washington, D.C., 2004. Available from: doi:10.17226/13545

[7] Baldwin DM. The Relation of Highway Design to Traffic Accident Experience. AASHTO, Convention Group Meeting, Washington, DC; 1946.

[8] Krammes RA, et al. Horizontal Alignment Design Consistency for Rural Two-lane Highways. Report no. FHWARD-94-034, FHWA, Washington D.C., 1995. Available from: https://rosap.ntl.bts.gov/view/dot/740/ dot_740_DS1.pdf?

[9] Pravilnik o osnovnim uvjetima kojima javne ceste izvan naselja i njihovi elementi moraju udovoljavati sa stajališta sigurnosti prometa. NN 110/2001. Available from: https://narodne-novine.nn.hr/clanci/sluzbeni/ 2001_12_110_1829.html

[10] Modeling Operating Speed. Washington DC: TRB; 2011. Available from: http://onlinepubs.trb.org/onlinepubs/circulars/ec151.pdf

[11] Chowdhury MA, Warren DL, Bissell H. Analysis of Advisory Speed Setting Criteria. Public Roads. 1991;55(3):65-71.

[12] McLean JR. Speeds, Friction Factors and Alignment Design Standards. Australian Road Research; 1988.

[13] Die Richtlinien für die Anlage von Straßen - Teil: Linienführung (kurz RAS-L), Germany, edition 1973, 1985, 1995.

[14] Choueiri EM, Lamm R, Kloeckner JH. Safety Aspects of Individual Design Elements and their Interactins on Two-lane Highways: International Perspective. Transportation Research Record. 1994;1445: 34-46. Available from: http://onlinepubs.trb.org/Onlinepubs/ trr/1994/1445/1445-004.pdf

[15] Ottesen J, Krammes RA. Speed-Profile Model for a Design Consistency Evaluation Procedure in the United States. Transportation Research Record. 2000;1701: 76-85. Available from: doi:10.3141/1701-10

[16] Fitzpatrick K, et al. Alternative design consistency rating methods for two-lane rural highways. Washington: Federal Highway Administration. Report No. FHWARD-99-172. 2000b. 
[17] Polus A, Fitzpatrick K, Fambro DB. Predicting operating speed on tangent sections of two lane rural highways. Transportation Research Record. 2000;1737: 50-57. Available from: doi:10.3141/1737-07

[18] Cvitanić D, Maljković B. Operating speed models of two-lane rural state roads developed on continuous speed dana. Tehnički vjesnik. 2017;24(6): 1915-1921. Available from: doi:10.17559/TV-20150304133437

[19] Fitzpatrick K, et al. Design Speed, Operating Speed, and Posted Speed Practices. NCHRP, report 504, 2003. Available from: http://onlinepubs.trb.org/ onlinepubs/nchrp/nchrp_rpt_504.pdf

[20] Said D, Hassan Y, Abd El Halim AO. Comfort thresholds for horizontal curve design. Canadian Journal of Civil Engineering. 2009;36(9): 1391-1402. Available from: doi:10.1139/L09-075

[21] A Policy on Geometric Design of Highways and Streets. American Association of State Highway and Transportation Officials (AASHTO); 2004.

[22] Forschungsgesellschaft für Straßen-und Verkehrswesen. Richtlinien $R 1$ für die Anlage von Landstraßen. Köln, Germany: FGSV Verlag GmbH; 2012. 